Lingua Rima: Jurnal Pendidikan Bahasa dan Sastra Indonesia

Vol. 11 No. 1 Januari 2022

http://jurnal.umt.ac.id/index.php/lgrm

\title{
PENGGUNAAN MEDIA FILM PENDEK DALAM KETERAMPILAN MENULIS NASKAH DRAMA KELAS XI MA AL-ITTIHAD PEDALEMAN SERANG
}

\author{
Azizatul Atiah ${ }^{1}$ \\ Universitas Islam Negeri Syarif Hidayatullah Jakarta ${ }^{1}$ \\ Azizatulatiah2698@gmail.com \\ Mahmudah Fitriyah ${ }^{2}$ \\ Universitas Islam Negeri Syarif Hidayatullah Jakarta ${ }^{2}$
}

\begin{abstract}
ABSTRAK
Penelitian ini tentang keterampilan menulis naskah drama dengan menggunakan media film pendek. Penelitian dilaksanakan pada peserta didik kelas XI MA Al-Ittihad Pedaleman. Penelitian bertujuan untuk mengetahui penerapan film pendek dalam menulis naskah drama dan mengetahui hasil kemampuan menulis naskah drama dengan menggunakan media film pendek pada peserta didik kelas XI MA Al-Ittihad Pedaleman Tahun Pelajaran 2020/2021. Metode yang digunakan dalam penelitian ini adalah metode deskriptif kualitatif. Teknik pengumpulan data dalam penelitian ini terdiri dari beberapa hal di antaranya: observasi, tes, wawancara, dan dokumentasi. Aspek yang dinilai dalam hasil menulis naskah drama yaitu kesesuaian judul dengan isi, kekuatan tokoh, kekuatan alur, kekuatan prolog, dan kekuatan epilog. Hasil penelitian menunjukkan bahwa ada 13 peserta didik memperoleh nilai dengan kualifikasi baik mencapai persentase $65 \%$ atau rata-rata nilainya 78 . Kemudian, 7 peserta didik memperoleh nilai dengan kualifikasi cukup mencapai persentse $35 \%$ atau rata-rata nilainya 69. Maka, peneliti menyimpulkan bahwa keterampilan menulis naskah drama dengan menggunakan media film pendek mampu memperbaiki nilai peserta didik dengan rata-rata nilainya 75 .
\end{abstract}

Kata Kunci: Naskah Drama, Media Film Pendek.

\section{A. PENDAhuluan}

Keterampilan berbahasa merupakan keterampilan yang harus dikuasai oleh setiap manusia, karena dengan keterampilan berbahasa akan mempermudah manusia dalam berkomunikasi. Bahasa berfungsi sebagai alat komunikasi yang bisa digunakan untuk menyampaikan suatu gagasan, ide, atau pemikiran. Pembelajaran keterampilan berbahasa memiliki empat tingkatan yang harus dikuasi oleh setiap manusia. Empat keterampilan berbahasa itu antara lain: keterampilan menyimak, keterampilan berbicara, keterampilan membaca, dan keterampilan menulis. Keterampilan menulis ini termasuk dalam keterampilan berbahasa tingkat akhir dengan aspek kegiatannya yang dianggap cukup sulit. 


\section{Lingua Rima: Jurnal Pendidikan Bahasa dan Sastra Indonesia \\ Vol. 11 No. 1 Januari 2022 \\ http://jurnal.umt.ac.id/index.php/lgrm}

Penugasan menulis juga bisa menjadi salah satu cara untuk latihan dalam penyusunan kata dan kalimat sehingga menjadi sebuah tulisan yang utuh.

Drama merupakan bentuk sastra yang dapat merangsang gairah dan mengasyikkan para pemain dan penonton sehingga digemari para penonton. Menulis naskah drama sangat penting diajarkan kepada peserta didik khususnya kelas XI, hal tersebut dikarenakan untuk melatih peserta didik menuangkan ide dan gagasannya melalui sebuah tulisan dan melihat kemampuan menulis naskah drama. Sesuai dengan keputusan Mentri Pendidikan dan Kebudayaan bahwa kegiatan belajar dan mengajar hanya bisa dilaksanakan secara daring dengan menggunakan media-media teknologi sebagai penunjang proses belajarnya.

Pada masa peralihan sistem belajar ini mengharuskan guru untuk kreatif dalam pemilihan media, karena pada hakikatnya media merupakan alat bantu yang bersifat meyakinkan pesan dan dapat merangsang pikiran, perasaan, dan kemauan audiens atau peserta didik. Proses belajar mengajar secara daring menimbulkan permasalahan baru, penggunaan media dan metode yang kreatif dan inovatif sangat penting sebagai penunjang keberhasilan pembelajaran. Salah satu media pembelajaran drama yang diharapkan mampu mempermudah peserta didik dalam proses menulis naskah drama adalah media film pendek. Hal ini dikarenakan media film pendek merupakan media yang mampu dikatakan sebagai media yang baru digunakan dalam proses belajar mengajar termasuk di sekolah MA Al-Ittihad Pedaleman.

Terbatasnya media pendukung dalam penayangan film pendek menjadi salah satu alasan guru tidak pernah menggunakan film pendek menjadi media pembelajaran. Adapun film pendek yang digunakan dalam penelitian ini adalah film "Tilik" atau dalam bahasa Indonesia berarti melihat. Film "Tilik" menceritakan tentang kehidupan di masa modern yang di mana masyarakat desa sudah mulai menggunakan media digital untuk mendapatkan informasi-informasi, namun informasi tersebut belum pasti kebenarannya. Hal ini sangat relevan pada kehidupan masyarakat Pedaleman khususnya peserta didik MA AL-Ittihad Pedaleman. Hasil penelitian ini berupa naskah drama dengan menggunakan media film pendek yang termasuk hal baru dilaksanakan di MA Al-Ittihad, hal tersebut dikarenakan tidak ada sarana dan prasarana penunjang media film, serta guru yang selalu menggunakan media ceramah, atau media buku paket Bahasa Indonesia. 


\section{Lingua Rima: Jurnal Pendidikan Bahasa dan Sastra Indonesia \\ Vol. 11 No. 1 Januari 2022 \\ http://jurnal.umt.ac.id/index.php/lgrm}

Berdasarkan latar belakang masalah tersebut maka dapat diketahu masalah yang muncul pada penulisan artikel ini adalah adanya peserta didik kurang tertarik dalam menulis naskah drama, adanya peserta didik mengalami kesulitan dalam menuangkan ide atau gagasan ke dalam bentuk naskah drama dan masih terdapat dewan guru yang kurang inovatif dan kreatif dalam menulis naskah drama dengan menggunakan media film pendek. Maka dari itu dapat diketahui bahwa tujuan pada penelitian ini adalah mengetahui kemampuan menulis naskah drama dengan menggunakan media film pendek pada peserta didik kelas XI IPA MA Al-Ittihad Pedaleman tahun pelajaran 2020/2021.

Media adalah alat saluran komunikasi, sedangkan pembelajaran adalah proses atau kegiatan yang sistematis dan sistemik bersifat interaktif dan komunikatif antara pendidik dan peserta didik.(Widyastuti et al., 2021) Jadi media pembelajaran merupakan alat berkomunikasi yang digunakan pendidik dalam menyampaikan materi kepada peserta didik.(Tafonao, 2018) Media memiliki banyak sekali macamnya dari media visual sampai media audiovisual masing-masing memiliki fungsi yang sama yakni sebagai alat bantu penunjang belajar mengajar.(Anas, 2014)

Film adalah gambar hidup, sering disebut juga movie. Film secara kolektif, sering disebut sinema. Film (sinema) secara harfiah adalah cinemathographie yang artinya melukis gerak dengan cahaya. Joseph M. Boggs and Dennis W. Petrie juga menyatakan film is recognized as a unique and powerful art form on a par with painting, sculpture, music, literature, nd drama. Like the drama, film communicates visually and verbally: visually, through action and gesture; verbally, through dialogue. Maksudnya, film merupakan media yang bisa digunakan untuk menayangkan sebuah gambar dan video.(Joseph \& Dennis, 2000)

Menulis yaitu suatu keterampilan berbahasa yang dipergunakan untuk berkomunikasi secara tidak langsung, tidak secara tatap muka dengan orang lain Menulis merupakan suatu kegiatan yang produktif dan ekspresif (Gulo \& Sidiqin, 2020). Menulis sediri merupakan keterampilan yang terakhir setelah keterampilan menyimak, keterampilan berbicara, dan keterampilan membaca (Khairunisa, 2017). Keterampilan menulis termasuk keterampilan yang tingkat kesulitannya masih terbilang sulit, tapi mampu diatasi dengan cara berlatih. 


\section{Lingua Rima: Jurnal Pendidikan Bahasa dan Sastra Indonesia \\ Vol. 11 No. 1 Januari 2022 \\ http://jurnal.umt.ac.id/index.php/lgrm}

Tujuan menulis sendiri yakni untuk memberikan informasi, menambah pengetahuan dan ilmu baru, serta menciptakan keindahan berupa tulisan (Ilham \& Wijiati, 2020).

Drama berasal dari bahasa Yunani draomai yang berarti perbutan, tindakan, atau aksi, jadi drama dapat diartikan sebagai perbutan atau tindakan (Karlina, 2017). Selain itu B. Rahmanto juga berpendapat mengenai makna drama, menurutnya drama merupakan bentuk sastra yang dapat merangsang gairah dan mengasyikkan para pemain dan penonton sehingga digemari masyarakat (Purwati, 2020). Drama yaitu sebuah gambaran kehidupan yang kemudian ditunjukkan dengan tujuan untuk menghibur. Sedangkan naskah drama adalah hasil dari penuangan ide dan gagasan berupa tulisan yang mampu menggambarkan kehidupan nyata. Drama sendiri memiliki banyak jenisnya, dari jenis drama yang pembahasannya serius sampai drama dengan semi komedi (Kusumawati, 2016).

\section{B. METODELOGI PENELITIAN}

Penelitian ini menggunakan metode deskriptif kualitatif. dilaksanakan di kelas XI IPA-1 MA Al-Ittihad Pedaleman. Penelitian ini dilaksanakan sejak bulan Maret 2020 sampai dengan bulan April 2021. Adapun pengambilan data dilaksanakan pada semester ganjil yakni 1-2 September 2020. Ada tiga tahap dalam pelaksanaan penelitian ini, tahap pertama perencanaan dan persiapan, tahan kedua pelaksanaan penelitian, dan tahap ketiga analisis data. Subjek pada penelitian ini yakni peserta didik kelas XI MA AL-Ittihad Pedaleman Tahun Pelajaran 2020/2021 yang pada awalnya berjumlah 31 peserta didik, namun ketika pengambilan data hanya ada 20 peserta didik. 11 peserta didik yang lainnya tidak berkenan hadir. Adapun objeknya yakni kemampuan menulis naskah drama peserta didik kelas XI MA AL-Ittihad Pedaleman Tahun Pelajaran 2020/2021 dengan menggunakan media film pendek yang berjudul "Tilik". Teknik pengumpulan data yang dilakukan ialah observasi ke sekolah untuk melihat kondisi lapangan menanyakan seputar pembelajaran bahasa Indonesia di MA Al-Ittihad. Kemudian teknik yang kedua ialah wawancara, wawancara yang dilakukan kepada guru bahasa Indonesia dan peserta didik kelas XI MA Al-Ittihad Pedaleman, teknik ketiga yakni dokumentasi. Adapun teknik analisis yang dilakukan yaitu dengan cara mereduksi data, menyajikan data, dan menyimpulkan data. 


\section{Lingua Rima: Jurnal Pendidikan Bahasa dan Sastra Indonesia \\ Vol. 11 No. 1 Januari 2022 \\ http://jurnal.umt.ac.id/index.php/lgrm}

\section{HASIL PENELITIAN DAN PEMBAHASAN}

Pada penelitian ini, dapat diidentifikasikan beberapa masalah yaitu: (a) Peserta didik kurang tertarik dalam menulis naskah drama; (b) Peserta didik mengalami kesulitan dalam menuangkan ide atau gagasan ke dalam bentuk naskah drama; (c) Guru kurang inovatif dan kreatif dalam menulis naskah drama dengan menggunakan media film pendek. Hasil karya tulis peserta didik pada penelitian ini ialah naskah drama. Adapun penilaian yang dilakukan oleh peneliti terhadap hasil karya tulis peserta didik mencangkup lima aspek, yakni kesesuaian judul dengan isi, kekuatan tokoh, kekuatan alur, dan kesatupaduan prolog dan epilog. Analisis hasil penelitian ini akan membandingkan antara hasil karya tulis naskah drama tanpa bantuan media film pendek dan hasil karya tulis naskah drama dengan menggunakan media film pendek. Hasil karya tulis naskah drama peserta didik akan dinilai dan direkap ke dalam tabel dan hasil karya tulis naskah drama peserta didik akan dinilai, dianalisis, dan kemudian direkap ke dalam tabel. Setelah mengetahui hasil dari karya tulis naskah drama baik menggunakan media ataupun tidak, selanjutnya peneliti akan membandingkan kedua penilaian tersebut.

\section{Tabel 4.5}

\section{Rekapitulasi Nilai Kemampuan Menulis Naskah Drama Sebelum} dan Sesudah Menggunakan Media Film Pendek

\begin{tabular}{|c|l|l|l|l|l|l|l|l|l|l|l|l|l|l|l|l|}
\hline No & $\begin{array}{l}\text { Nama } \\
\text { Peserta } \\
\text { Didik }\end{array}$ & \multicolumn{1}{|c|}{ Sebelum Menggunakan Media } & A & B & C & D & E & HS & K & A & B & C & D & E & $\begin{array}{c}\text { H } \\
\text { S }\end{array}$ & K \\
\hline 1. & $\begin{array}{l}\text { Aan } \\
\text { Mubarok }\end{array}$ & - & - & - & - & - & - & - & - & - & - & - & - & - & - \\
\hline 2. & $\begin{array}{l}\text { Ardiansya } \\
\text { h }\end{array}$ & - & - & - & - & - & - & - & - & - & - & - & - & - & \\
\hline 3. & Ashang & 10 & 10 & 15 & 15 & 15 & 60 & C & 20 & 10 & 15 & 20 & 15 & 80 & B \\
\hline 4. & $\begin{array}{l}\text { David } \\
\text { Rapel } \\
\text { Ayadi }\end{array}$ & - & - & - & - & - & - & - & - & - & - & - & - & - & - \\
\hline 5. & Duriyanti & 10 & 15 & 10 & 15 & 15 & 65 & C & 20 & 10 & 15 & 15 & 10 & 80 & B \\
\hline 6. & Elisah & 15 & 10 & 10 & 15 & 10 & 60 & C & 20 & 15 & 10 & 15 & 10 & 70 & C \\
\hline 7. & $\begin{array}{l}\text { Evan } \\
\text { Hidayatull } \\
\text { ah }\end{array}$ & - & - & - & - & - & - & - & - & - & - & - & - & - & - \\
\hline
\end{tabular}


Lingua Rima: Jurnal Pendidikan Bahasa dan Sastra Indonesia

Vol. 11 No. 1 Januari 2022

http://jurnal.umt.ac.id/index.php/lgrm

\begin{tabular}{|c|c|c|c|c|c|c|c|c|c|c|c|c|c|c|c|}
\hline 8. & $\begin{array}{l}\text { Farhatul } \\
\text { Layali }\end{array}$ & 20 & 10 & 10 & 15 & 10 & 65 & $\mathrm{C}$ & 20 & 20 & 10 & 15 & 10 & 80 & B \\
\hline 9. & $\begin{array}{l}\text { Gugun } \\
\text { Gunadi }\end{array}$ & - & - & - & - & - & - & - & - & - & - & - & - & - & - \\
\hline 10. & $\begin{array}{l}\text { Indra } \\
\text { Aldira }\end{array}$ & - & - & - & - & - & - & - & - & - & - & - & - & - & - \\
\hline 11. & Indrayani & - & - & - & - & - & - & - & - & - & - & - & - & - & - \\
\hline 12. & $\begin{array}{l}\text { Jajang } \\
\text { Supriadi }\end{array}$ & - & - & - & - & - & - & - & - & - & - & - & - & - & - \\
\hline 13. & Jihan & 10 & 10 & 10 & 10 & 10 & 50 & $\mathrm{D}$ & 15 & 10 & 10 & 15 & 15 & 70 & $\mathrm{C}$ \\
\hline 14. & $\begin{array}{l}\text { Kholilatul } \\
\text { Fatiroh }\end{array}$ & 10 & 10 & 10 & 15 & 10 & 55 & $\mathrm{D}$ & 10 & 10 & 10 & 15 & 15 & 70 & $\mathrm{C}$ \\
\hline 15. & $\begin{array}{l}\text { Lulu } \\
\text { Lukmiyati }\end{array}$ & 15 & 10 & 10 & 15 & 15 & 65 & $\mathrm{C}$ & 20 & 10 & 15 & 15 & 10 & 75 & B \\
\hline 16. & Maisyah & 20 & 10 & 10 & 20 & 15 & 70 & $\mathrm{C}$ & 20 & 10 & 10 & 15 & 15 & 80 & $\mathrm{~B}$ \\
\hline 17. & $\begin{array}{l}\text { Mita } \\
\text { Amelia }\end{array}$ & 10 & 10 & 10 & 15 & 10 & 55 & $\mathrm{D}$ & 20 & 10 & 10 & 15 & 15 & 75 & B \\
\hline 18. & $\begin{array}{l}\text { Muhamad } \\
\text { Faris }\end{array}$ & 15 & 10 & 10 & 15 & 10 & 60 & $\mathrm{C}$ & 20 & 10 & 15 & 15 & 10 & 75 & B \\
\hline 19. & $\begin{array}{l}\text { Musfik } \\
\text { Amrullah }\end{array}$ & 10 & 10 & 10 & 15 & 10 & 55 & $\mathrm{D}$ & 15 & 10 & 10 & 15 & 10 & 65 & $\bar{C}$ \\
\hline 20. & $\begin{array}{l}\text { Najwa } \\
\text { Rahmatull } \\
\text { ah }\end{array}$ & 15 & 15 & 10 & 20 & 5 & 65 & $\mathrm{C}$ & 20 & 15 & 10 & 15 & 10 & 70 & $\mathrm{C}$ \\
\hline 21. & $\begin{array}{l}\text { Nasihul } \\
\text { Umam }\end{array}$ & 15 & 10 & 10 & 5 & 10 & 55 & $\mathrm{D}$ & 20 & 15 & 10 & 15 & 15 & 75 & B \\
\hline 22. & $\begin{array}{l}\text { Nurhikma } \\
\mathrm{h}\end{array}$ & 10 & 15 & 15 & 15 & 15 & 70 & $\mathrm{C}$ & 20 & 15 & 15 & 20 & 15 & 85 & B \\
\hline 23. & $\begin{array}{l}\text { Pika Suci } \\
\text { Yanti }\end{array}$ & 15 & 10 & 10 & 20 & 10 & 65 & $\mathrm{C}$ & 15 & 20 & 15 & 15 & 10 & 75 & B \\
\hline 24. & Rijal & 15 & 10 & 10 & 15 & 5 & 55 & $\mathrm{D}$ & 20 & 10 & 15 & 15 & 15 & 75 & $\mathrm{~B}$ \\
\hline 25. & $\begin{array}{l}\text { Rizky } \\
\text { Altsani }\end{array}$ & 10 & 10 & 10 & 15 & 15 & 60 & $\mathrm{C}$ & 20 & 15 & 15 & 20 & 15 & 85 & B \\
\hline 26. & Safitri & 15 & 10 & 10 & 15 & 10 & 60 & $\mathrm{C}$ & 10 & 10 & 15 & 15 & 10 & 70 & $\mathrm{C}$ \\
\hline 27. & Sahrul & - & - & - & - & - & - & - & - & - & - & - & - & - & - \\
\hline 28. & Sarju & - & - & - & - & - & - & - & - & - & - & - & - & - & - \\
\hline 29. & $\begin{array}{l}\text { Sofiyaturr } \\
\text { okhimah }\end{array}$ & 10 & 10 & 10 & 10 & 10 & 50 & $\mathrm{D}$ & 15 & 10 & 10 & 20 & 10 & 75 & B \\
\hline 30. & Suciwati & 10 & 10 & 10 & 15 & 10 & 55 & $\mathrm{D}$ & 20 & 10 & 15 & 15 & 10 & 70 & $\mathrm{C}$ \\
\hline 31. & $\begin{array}{l}\text { Syahrul } \\
\text { Anwar }\end{array}$ & - & - & - & - & - & - & - & - & - & - & - & - & - & - \\
\hline \multicolumn{7}{|c|}{ Jumlah } & \multicolumn{2}{|c|}{60} & \multicolumn{5}{|c|}{ Jumlah } & \multicolumn{2}{|c|}{75} \\
\hline
\end{tabular}

\section{Keterangan:}
A: Kesesuaian Judul dengan Isi
E: Kekuatan Epilog
B: Kekuatan Tokoh
HS: Hasil 


\section{Lingua Rima: Jurnal Pendidikan Bahasa dan Sastra Indonesia \\ Vol. 11 No. 1 Januari 2022 \\ http://jurnal.umt.ac.id/index.php/lgrm}
C: Kekuatan Alur
K: Kriteria
D: Kekuatan Prolog

\section{Kriteria Penilaian:}
SB: Sangat Baik
B: Baik
C: Cukup
D: Kurang

Tabel di atas merupakan rekapan hasil penelitian keterampilan menulis naskah drama tanpa menggunakan media dan keterampilan menulis naskah drama dengan menggunakan media. Pada tes keterampilan menulis naskah drama sebelum menggunakan media, penulis dapat memperoleh data sebanyak 20 peserta didik dengan nilai rata-rata 60 . Sedangkan, pada tes keterampilan menulis naskah drama dengan menggunakan media, penulis dapat memperoleh data sebanyak 20 dengan nilai rata-rata 75 . Dengan demikian, dapat diketahui bahwa nilai tertinggi pada tes keterampilan menulis naskah drama sebelum menggunakan media film pendek ini diperoleh Maisyah dan Nurhikmah memperoleh skor 70. Nilai sedang pada tes keterampilan menulis naskah drama sebelum menggunakan media film pendek diperoleh Duriyanti dengan skor 65. Nilai terendah pada tes keterampilan menulis naskah drama sebelum menggunakan media film pendek diperoleh Sofiyaturrokhimah dan Jihan dengan sama memperoleh skor 50. Sedangkan, nilai tertinggi pada tes keterampilan menulis naskah drama setelah menggunakan media film pendek ini diperoleh Nurhikmah dan Rizky Altsani memperoleh skor 85. Nilai sedang pada tes keterampilan menulis naskah drama setelah menggunakan media film pendek diperoleh Ashang, Duriyanti, Farhatul Layali, dan Maisyah dengan masing-masing memperoleh skor 80. Nilai terendah pada tes keterampilan menulis naskah drama setelah menggunakan media film pendek diperoleh Musfik Amrullah dengan memperoleh skor 65 .

Setelah melakukan perhitungan persentase dapat diketahui bahwa ada 13 peserta didik memperoleh nilai dengan kualifikasi baik mencapai persentase $65 \%$ atau rata-rata nilainya 78. Kemudian, 7 peserta didik memperoleh nilai dengan kualifikasi cukup mencapai persentse $35 \%$ atau rata-rata nilainya 69 . Berikut ini diagram dan persentase keterampilan menulis naskah drama dengan menggunakan media film pendek yang sesuasi dengan nilai rata-rata sebagai berikut. 


\section{Diagram 4.1}

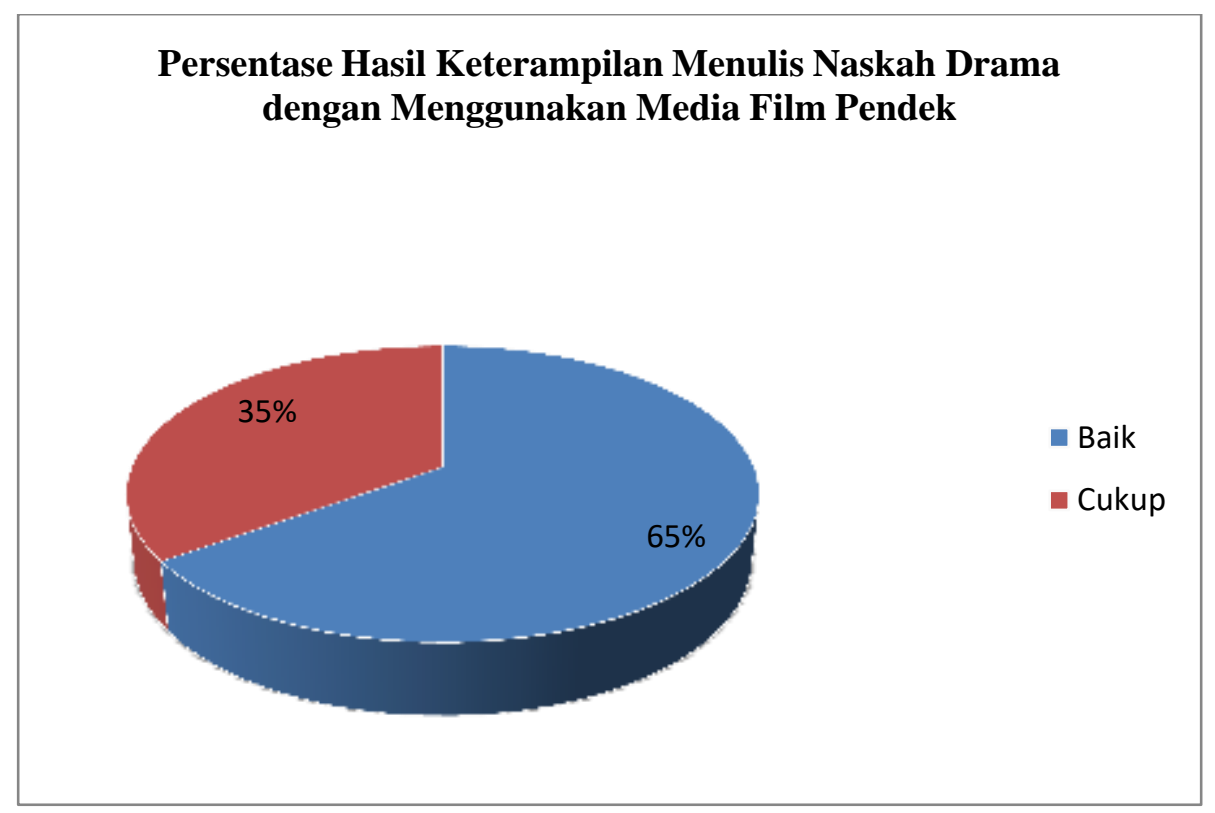

Berdasarkan diagram di atas, dapat diketahui bahwa peserta didik yang memperoleh nilai dengan katagori baik ada 13 peserta didik dengan persentase 65\% yakni pada rentang nilai 76-85. Sementara itu, peserta didik yang memperoleh nilai dengan katagori cukup ada 7 peserta didik dengan persentase $35 \%$ yakni pada rentang nilai 56-75

\section{SIMPULAN DAN SARAN}

Berdasarkan hasil analisis penelitian yang telah dilakukan oleh peneliti, maka dapat disimpulkan bahwa penggunaan media film pendek dapat membantu memudahkan menulis naskah drama pada peserta didik kelas XI IPA 1 MA Al-Ittihad Pedaleman, Serang tahun pelajaran 2020/2021. Hal tersebut dapat dibuktikan dari kualifikasi nilai yang diperoleh peserta didik dengan nilai rata-rata 75 . Hasil dari rekapitulasi analisis data menunjukkan bahwa 13 peserta didik memperoleh nilai dengan kualifikasi baik mencapai persentase $65 \%$ atau rata-rata nilainya 78 . Kemudian, 7 peserta didik memperoleh nilai dengan kualifikasi cukup mencapai persentse 35\% atau rata-rata nilainya 69. Keterampilan menulis naskah drama setelah menggunakan media film pendek mengalami kenaikan nilai rata-rata 75 dengan katagori baik. Hal ini berbeda dengan keterampilan menulis naskah sebelum menggunakan media film pendek yang hanya memperoleh nilai rata-rata 60. Setelah 


\section{Lingua Rima: Jurnal Pendidikan Bahasa dan Sastra Indonesia \\ Vol. 11 No. 1 Januari 2022 \\ http://jurnal.umt.ac.id/index.php/lgrm}

menunjukkan nilai tersebut, maka dapat disimpulkan bahwa film pendek mampu menjadi inovasi guru dalam memilih media khususnya pada keterampilan menulis naskah drama. Berdasarkan penelitian, masih terdapat kekurangan pada peserta didik yakni masih sulit dalam menuangkan ide atau gagasan ke dalam bentuk naskah drama.

Berdasarkan hasil penelitian dan kesimpulan yang telah dipaparkan, maka dapat peneliti sampaikan beberapa saran yaitu bagi guru Media film pendek dapat dimanfaatkan dalam pembelajaran Bahasa Indonesia, khususnya naskah drama. Media film pendek ini mampu menarik perhatian peserta didik dalam belajar dan mampu meningkatkan pemahaman pada materi. Namun, kemampuan peserta didik dalam menulis naskah drama masih kurang, terlihat dari aspek pemilihan judul, menulisan tokoh, alur naskah, prolog dan epilog naskah drama. Oleh karenanya, peserta didik memerlukan pelatihan dalam hal tersebut. Bagi sekolah, sekolah sebagai lembaga pendidikan sebaiknya mampu menyediakan sarana dan prasarana yang cukup memadai sebagai pembelajaran, agar peserta didik tidak mudah bosan dalam belajar. Bagi peneliti selanjutnya bisa menggunakan media film pendek sebagai referensi media penunjang materi pelajaran Bahasa Indonesia.

\section{E. DAFTAR PUSTAKA}

Endaswara, Suwardi. 2011. Metode Pembelajaran Drama, Yogyakarta: CAPS.

Guntur Tarigan, Henry. 2008. Menulis Sebagai Suatu Keterampilan Berbahasa. Bandung: Angkasa.

Hamalik, Oemar. 2014. Kurikulum dan Pembelajaran. Jakarta: Bumi Aksara.

Indriana, Dina. 2011. Ragam Alat Bantu Media Pengajaran. Jogjakarta: DIVA Press.

M. Boggs, Joseph and W. Petrie, Dennis. 2008. The Art of Watching Films, seventh edition, New York: Mc Graw Hill.

Nuryanto, Tato. 2017. Apresiasi Drama. Depok: PT Raja Grafindo Persada.

Rahmanto, B. 1988. Metode Pengajaran Sastra. Yogyakarta: Kanisius. 1988.

S. Rocco, Tonette dan Tim Hatcher. 2011. The Handbook of Scholarly Writing and Publishing, (San Francisco: Jossey-Bass, 2011), h. 4. 


\section{Lingua Rima: Jurnal Pendidikan Bahasa dan Sastra Indonesia \\ Vol. 11 No. 1 Januari 2022 \\ http://jurnal.umt.ac.id/index.php/lgrm}

Sukiman. 2012. Pengembangan Media Pembelajaran. Yogyakarta: Pustaka Insan Madani.

WS, Hasanuddin. 2015. Drama Karya Dalam Dua Dimensi. Bandung: Angkasa. 